\title{
Analysis of Global DNA Methylation in Irradiated Fig Selections
}

\author{
Maria Gabriela Fontanetti Rodrigues*, Murilo Racy Soares, \\ Ester Silveira Ramos, Silvana Giuliatti \\ Departament do Genetics at the University of Sao Paulo Medical School, University of São Paulo, \\ Ribeirão Preto, Brazil \\ Email: 'gabrielafontanetti@usp.br, murilors@usp.br, esramos@fmrp.usp.br, silvana@fmrp.usp.br
}

Received 30 July 2015; accepted 1 September 2015; published 4 September 2015

Copyright (C) 2015 by authors and Scientific Research Publishing Inc.

This work is licensed under the Creative Commons Attribution International License (CC BY). http://creativecommons.org/licenses/by/4.0/

c) (i) Open Access

\section{Abstract}

Fruits from fig tree (Ficus carica L.) are economically important worldwide, and rank among the top 20 fruits exported by Brazil. However, due to particular features in its floral structure, classical plant breeding procedures that involve hybridization are not possible. Thus, genetic improvement of figs by using mutagens is an important line of research. In this study, five fig selections based on their interesting agronomic features were used. Genetic modifications associated with mutations were not detected by molecular markers. Therefore, it was suggested that certain phenotypes could have resulted from epigenetic modifications. The best characterized epigenetic modification is DNA methylation, which can switch genes on or off by acting as a signal. After epigenetic polymorphisms were identified by methylation sensitive amplified polymorphism (MSAP) molecular markers, we quantified the level of DNA methylation in fig selections irradiated with gamma rays and compared it to levels in the commercial cultivar "Roxo-de-Valinhos." This was achieved by analyzing the global methylation using an Imprint Methylated DNA Quantification kit. The results showed that there were significant differences in global methylation following different treatments, indicating that irradiation was an abiotic factor that could alter the epigenome of plants. Since the material used as a control was also found to be methylated, demethylation of the polymorphic genomic material might account for the phenotypic variations observed among different treatment groups. These results suggest that irradiation is an external factor that is capable of altering epigenetic patterns.

\section{Keywords}

Epigenetics, Methylation, Mutagenic, Ficus carica

\footnotetext{
${ }^{*}$ Corresponding author.

How to cite this paper: Rodrigues, M.G.F., Soares, M.R., Ramos, E.S. and Giuliatti, S. (2015) Analysis of Global DNA Methylation in Irradiated Fig Selections. American Journal of Plant Sciences, 6, 2257-2262. 


\section{Introduction}

Epigenetic changes involve DNA methylation, and modification of histones and small regulatory RNAs [1]. In plants, epigenetic regulation is involved in the development, differentiation, plant responses to the environment, such as biotic and abiotic stress [2]-[4], and DNA methylation, which is an epigenetic marker involved in silencing of transposable elements and genomic imprinting [5]-[10].

Epigenetic modifications affect chromatin dynamics, and determine whether they are in an active euchromatin or an inactive or silenced heterochromatin state. Changes in chromosome density influence the access of proteins to binding sites on the DNA, including RNA transcriptases and various transcription factors, subsequently modulating gene expression [2] [11], thus allowing or preventing gene transcription through the modification of epigenetic markers.

These epigenetic modifications consist of changes at key sites in the molecules that form the chromatin, particularly in the loose amino acid chains found in histones, and in the DNA bases themselves. This commonly involves methylation of position five on the pyrimidine ring in cytosine. Chromatin remodeling and nuclear reorganization have also been shown to be involved in plant responses to stress [12], and stress can affect chromatin spatial disposition [13], thus interfering directly with the individual plasticity of an organisms' phenotype.

Programs aiming to improve fig trees using conventional procedures to obtain new cultivars are rare in many countries, such as Brazil. This is especially due to the low genetic variability and difficulties in obtaining plants from gamete fusion, as the wasp Blastophaga psenes that is responsible for natural pollination is not found in Brazil [14]. Thus, mutagenic genetic improvement is an important field of research in crop science; and obtaining information about this species, especially regarding its genetic variability is necessary so that appropriate propagation and management projects can be developed.

Low dose radiation can stimulate various biological processes and has been applied in different fields to produce mutant plants that can be used to improve crops [15]. From fig cuttings of the cultivar "Roxo-de-Valinhos" irradiated with gamma rays at a dose of $30 \mathrm{~Gy}$ [16], it was possible to select plants based on their unique and divergent morphological characteristics, and agronomic interest [17]. However, no polymorphisms were observed in irradiated figs subjected to molecular analysis, including random amplified polymorphic DNA (RAPD) and amplified fragment length polymorphism (AFLP) techniques, indicating that no genetic modifications had occurred. This suggested that epigenetic changes were responsible for the different characteristic observed between treatments following gamma radiation [18]. Following irradiation, changes in global DNA methylation were detected using methylation-sensitive amplification polymorphism (MSAP) molecular markers [19]. This study evaluated global DNA methylation and chromatin in irradiated fig selections and compared it with that observed in the commercial cultivar "Roxo-de-Valinhos".

\section{Materials and Methods}

The experiment was conducted at the Epigenetics and Reproduction Laboratory of Medicine School of Ribeirão Preto (São Paulo, Brazil), using leaves of five selected irradiated plants based on their unique morphological characteristics [17]. The specimens consisted of cuttings irradiated with gamma rays, at the dose of $30 \mathrm{~Gy}$, with 238 Gy.hour $^{-1}$ dose rate, at the Energy Nuclear Center in Agriculture (Piracicaba, Brazil). The treatments are listed below:

1) Roxo-de-Valinhos cultivar-control.

2) Irradiated Plant Selection-440 (IP-440).

3) Irradiated Plant Selection-433 (IP-433).

4) Irradiated Plant Selection-189 (IP-189).

5) Irradiated Plant Selection-214 (IP-214).

6) Irradiated Plant Selection-301 (IP-301).

\subsection{Interest Agronomic Characteristics of Treatments}

The fruits of the Roxo-de-Valinhos variety present rind with purple-violet dark color, reaching up to $7.5 \mathrm{~cm}$ in length and 60 to 90 grams of weight [20]. They are oval in shape, short and thick neck, almost without separation boundary with the receptacle body. They present lightly grooved surfasse and large and open ostiole, even in green figs. 
Being unique and different compared to the Roxo-de-Valinhos control, irradiated treatments showed the following characteristics of agronomic interest: treatment 2 presented elongated fruits, i.e., the length, at least, twice longer than the diameter.

Treatment 3 presented low brix content and long stems, or simply the presence of stems, once the control has not. The presence of stem facilitates harvest and increases the shelf life of fruits, essential for exportation.

The treatment 4, presented as characteristics of agronomic interest, high levels of brix and large fruit, weighing more than the fruits control, with small and closed ostiole. This fact reduces the incidence of pests and avoids the depreciation of the fruits with possible cracks in the rind.

Treatment 5 presented large fruit, i.e., weighing more than the fruits control, along with the fruits of treatment 6, which in addition to large fruits, had elongated format and high brix content.

\subsection{Relative Quantification of Global DNA Methylation}

Young leaves without spots or perforations were collected and washed under running water, and their veins were removed. Total genomic DNA was extracted from plant tissues using a modified cetyltrimethylammonium bromide technique [21].

Global DNA methylation was quantified using the Imprint DNA Methylation Quantification kit (Sigma), following the manufacturer's instructions. This kit functions similarly to an ELISA plate assay, and uses strips of wells that have been pre-treated to allow binding of methylated DNA. The methylated DNA is then detected using Anti-5-Methylcytosine monoclonal antibod and reagents with high specificity to $5 \mathrm{mC}$. The performance of the assay was determined colorimetrically and the absorbance was recorded using a microplate reader at $450 \mathrm{~nm}$ (Biotek Power Wave XS). The percentage of DNA methylation can then be calculated relative to an internal standard of methylated control DNA that is supplied in the kit, wherein the higher absorbance at $450 \mathrm{~nm}$ means higher DNA methylation.

The following steps were followed: 1) the A450 replicates for the blank, samples and methylated control DNA were averaged and 2) the formula ((A450 av sample-A450 av blank)/(A450 av methylated control DNAA450 av blank) $) \times 100$ was used to calculate the percentage methylation of samples compared to that of the methylated control DNA.

Differences in DNA methylation between treatment groups were evaluated using one-way Analysis of Variance (ANOVA). Prior to the analysis, the percentage of methylated DNA was log transformed to validate the assumptions of ANOVA. Post-hoc analysis was performed with Tukey’s test for a 95\% level of confidence (P < 0.05).

\section{Results and Discussion}

To determine whether the plasticity of DNA methylation is related to stress induced by irradiation, we investigated global DNA methylation in response to radiation treatment, using Imprint ${ }^{\text {TM }}$ Methylated DNA Quantification technology (Sigma-Aldrich), which assesses the spatial distribution of 5-methylcytosine sites and thus detects methylated cytosine residues.

According to the analysis of variance, an F-test for a 95\% level of confidence, there was a statistically significant difference in the percentage of methylated DNA between the treatment groups. A post-hoc analysis of the average percentages showed that treatment three (IP 433-long stalk) leads to lower levels of global methylation, than any other medium, is not, however, statistically different, of the treatment non-irradiated control "Roxo-deValinhos" (Table 1).

The irradiated control had a lower level of global methylation compared with that observed following other treatments, suggesting that radiation is an external stressor that is capable of altering methylation patterns in plants.

The use of an ELISA assay to quantify global DNA methylation is a relatively new method in plants, which so far, has only been used to quantify DNA methylation in the cork oak genome [22]. In the present study, changes in global DNA methylation were detected after irradiation imposition. Hypo- and hypermethylated DNA modulates gene transcription in plants and occurs under conditions of environmental stress induced by cold, heat and/or salinity [23] [24].

Differences in the level of global DNA methylation were found between rice varieties in response to salt stress using an ELISA assay. Mutations in epigenetic regulators affected specific phenotypic parameters related 
Table 1. Results of ELISA assays read at $450 \mathrm{~nm}$ and the corresponding analysis of variance. Numbers 1 - 6 refer to the following phenotypes: 1—“Roxo-de Valinhos”; 2-IP 440; 3-IP 433; 4-IP 189; 5-IP 214; and 6-IP 301.

\begin{tabular}{cccc}
\hline Treatments & $\begin{array}{c}\text { Absorbance at } 450 \mathrm{~nm} \\
\text { first analysis }\end{array}$ & $\begin{array}{c}\text { Absorbance at } 450 \mathrm{~nm} \\
\text { second analysis }\end{array}$ & $\begin{array}{c}\text { Relative quantification of } \\
\text { methylated DNA (\%) }\end{array}$ \\
\hline 1 & 0.615 & 0.661 & $16.62 \mathrm{ab}$ \\
2 & 0.637 & 0.811 & $18.75 \mathrm{a}$ \\
3 & 0.370 & 0.479 & $20.99 \mathrm{~b}$ \\
4 & 0.714 & 0.886 & $20.29 \mathrm{a}$ \\
5 & 0.670 & 0.900 & $25.21 \mathrm{a}$ \\
Methylated DNA control & 0.835 & 1.115 & - \\
CV\% & 3.586 & 4.109 & 5.61 \\
\hline
\end{tabular}

Means followed by the same letter do not differ by Tukey’s test at a 95\% level of confidence.

to salinity tolerance, such as the root length and biomass, reinforcing the need for a better understanding of the association between epigenetic networks and plant responses to environmental stresses [25].

Physical (different types of radiation) and chemical mutagens can be used in vivo or in vitro during plant breeding to increase genetic variability and allow genotypes of interest to be obtained [26]. In figs, dormant buds were irradiated with gamma-rays and the LD50 (dose causing 50\% lethality) was determined as 25 Gy; however, a preliminary test should be performed for each genotype before the start of any study [27]. Cuttings of axillary buds were treated with gamma rays (50 - $100 \mathrm{~Gy}$ ) and small, earliness mutants were obtained. These were tested for use in production, and one of them (Bol) was subsequently released to producers [28].

Using different doses of gamma radiation in Arabidopsis thaliana, a decrease in DNA methylation was observed with an increasing radiation dose. These results showed that radiation at a dose of $200 \mathrm{~Gy}$ was associated with a substantial reduction in the transcriptional silencing of genes, probably due to induction of genomic hypomethylation [29].

Analysis of global DNA methylation in irradiated figs showed that the effects of radiation do not affect the genomes of different selections in a homogeneous manner. However, demethylation of parts of the genome is likely, since the most polymorphic bands were observed in this condition [19].

DNA methylation in Arabidopsis thaliana as a repressive mark is often associated with the expression of transcriptionally inactive repetitions, such as repetitive sequences, transposons, and heterochromatic [30] [31]. Methylated DNA loci are often followed by small interfering RNAs (RNAi) [32] [33], which regulates heterochromatin function and plays an important role in DNA methylation, such as the control of silencing [34] [35] [1].

In the present study, treatment three showed that radiation affects the silencing system. This breaks the equilibrium certainly caused an increase in expression of these satellite sequences, forcing the RNAi system to an expression control. Recruitment of the silencing system to a great extent the genome may have caused an imbalance in the silencing coding and/or promoters regions of genes, namely a strong demethylation of these sequences.

DNA methylation can be established and maintained in plants and animals. When methylation pathways are inactivated, the effects of DNA methylation are diluted following cellular replication leading to passive DNA demethylation. In other cases, however, DNA methylation is removed by active DNA demethylation. Active or passive DNA demethylation simultaneously reduces the level of DNA methylation at specific developmental stages [30].

The genome of superior plants contains many transposable elements that potentially disturb the stability of the genome. In plants, DNA methylation usually occurs in these transposable elements. Loss of DNA methylation in mutant genes responsible for it leads to the disruption of transcriptional silencing of transposable elements and other repetitive DNA sequences, thus generating different phenotypes [35].

\section{Conclusion}

Variation in the level of DNA methylation in different selections of fig irradiated with gamma rays is observed, 
indicating that this abiotic factor can affect the epigenome of plants, leading to the generation of different phenotypes, and being a pioneer of new data in fig crops.

\section{Acknowledgements}

This research was supported by Research Support Foundation of São Paulo State (FAPESP) with a PhD scholarship to M. G. F. Rodrigues, and the Post Graduate Program in Genetics of University of Sao Paulo Medical School. We also acknowledge Dra. Fabiani Gai Frantz and Luana Silva Soares for their support completing the ELISA analysis.

\section{References}

[1] Jones, A.L. and Sung, S. (2014) Mechanisms Underlying Epigenetic Regulation in Arabidopsis thaliana. Integrative and Comparative Biology, 54, 61-67. http://dx.doi.org/10.1093/icb/icu030

[2] Pecinka, A., Dinh, H.Q., Baubec, T., Rosa, M., Lettner, N. and Mittelsten Scheid, O. (2010) Epigenetic Regulation of Repetitive Elements Is Attenuated by Prolonged Heat Stress in Arabidopsis. The Plant Cell, 22, 3118-3129.

http://dx.doi.org/10.1105/tpc.110.078493

[3] Tittel-Elmer, M., Bucher, E., Broger, L., Mathieu, O., Paszkowski, J. and Vaillant, I. (2010) Stress-Induced Activation of Heterochromatic Transcription. PLOS Genetics, 6, Article ID: e1001175. http://dx.doi.org/10.1371/journal.pgen.1001175

[4] Hauser, M.T., Aufsatz, W., Jonak, C. and Luschnig, C. (1809) Transgenerational Epigenetic Inheritance in Plants. Biochimica et Biophysica Acta, 1809, 459-468.

[5] Okamoto, H. and Hirochika, H. (2001) Silencing of Transposable Elements in Plants. Trends in Plant Science, 6, 527534. http://dx.doi.org/10.1016/S1360-1385(01)02105-7

[6] Kato, M., Takashima, K. and Kakutani, T. (2004) Epigenetic Control of CACTA Transposon Mobility in Arabidopsis thaliana. Genetics, 168, 961-969. http://dx.doi.org/10.1534/genetics.104.029637

[7] Rangwala, S.H. and Richards, E.J. (2007) Differential Epigenetic Regulation within an Arabidopsis Retroposon Family. Genetics, 176, 151-160. http://dx.doi.org/10.1534/genetics.107.071092

[8] Saze, H. and Kakutani, T. (2007) Heritable Epigenetic Mutation of a Transposon Flanked Arabidopsis Gene Due to Lack of the Chromatin-Remodeling Factor DDM1. The EMBO Journal, 26, 3641-3652.

http://dx.doi.org/10.1038/sj.emboj.7601788

[9] Henderson, I.R. and Jacobsen, S.E. (2008) Tandem Repeats Upstream of the Arabidopsis Endogene SDC Recruit NonCG DNA Methylation and Initiate siRNA Spreading. Genes, 22, 1597-1606. http://dx.doi.org/10.1101/gad.1667808

[10] Lisch, D. (2009) Epigenetic Regulation of Transposable Elements in Plants. Annual Review of Plant Biology, 60, 4366. http://dx.doi.org/10.1146/annurev.arplant.59.032607.092744

[11] Mahfouz, M.M. (2010) RNA-Directed DNA Methylation: Mechanisms and Functions. Plant Signaling \& Behavior, 5, 806-816. http://dx.doi.org/10.4161/psb.5.7.11695

[12] Kim, J.M., To, T.K., Nishioka, T. and Seki, M. (2010) Chromatin Regulation Functions in Plant Abiotic Stress Responses. Plant, Cell \& Environment, 33, 604-611. http://dx.doi.org/10.1111/j.1365-3040.2009.02076.x

[13] Santos, A.P., Ferreira, L., Maroco, J. and Oliveira, M.M. (2011) Abiotic Stress and Induced DNA Hypomethylation for Rice rDNA Loci. Cytogenetic and Genome Research, 132, 297-303. http://dx.doi.org/10.1159/000322287

[14] Ferreira, E.A., Pasqual, M. and Tulmann Neto, A. (2009) In Vitro Sensitivity of Fig Plantlets to Gamma Rays. Scientia Agricola, 66, 540-542. http://dx.doi.org/10.1590/S0103-90162009000400017

[15] Wang, H., Feng, Q., Zhang, M., Yang, C., Sha, W. and Liu, B. (2010) Alteration of DNA Methylation Level and Pattern in Sorghum (Sorghum bicolor L.) Pure-Lines and Inter-Line F1 Hybrids Following Low-Dose Laser Irradiation. Journal of Photochemistry and Photobiology B: Biology, 99, 150-153. http://dx.doi.org/10.1016/j.jphotobiol.2010.03.011

[16] Santos, P.C., Correa, L.S., Tulmann Neto, A. and Boliani, A.C. (1997) Sensitividade de estacas de figo a radiação gama. Revista Brasileira de Genética, 20, 150.

[17] Rodrigues, M.G.F., Corrêa, L.S., Santos, P.C. and Tulmann Neto, A. (2012) Seleção de Clones de Figueira cv. Roxode-Valinhos Formados por Gemas Irradiadas. Revista Brasileira de Fruticultura, 34, 604-611. http://dx.doi.org/10.1590/S0100-29452012000200036

[18] Rodrigues, M.G.F., Martins, A.B.G., Desiderio, J.A., Bertoni, B.W. and Alves, M.C. (2012) Genetic Characterization of Fig Tree Mutants by Molecular Markers. Genetics and Molecular Research, 11, 1990-1996. 
http://dx.doi.org/10.4238/2012.August.6.3

[19] Rodrigues, M.G.F., Martins, A.B.G., Bertoni, B.W., Figueira, A. and Giuliatti, S. (2013) Search for Methylation-Sensitive Amplification Polymorphisms in Mutant Figs. Genetics and Molecular Research, 12, 2267-2280. http://dx.doi.org/10.4238/2013.July.8.8

[20] Rigitano, O. (1955) A figueira cultivada no Estado de São Paulo. 1955. 59 f. Tese (Doutorado em Fitotecnia), Escola Superior de Agricultura "Luiz de Queiroz”, Universidade de São Paulo, Piracicaba.

[21] Lodhi, M.A., Guang-Ning, Y., Norman, F.W. and Bruce, I.R. (1994) A Simple and Efficient Method for DNA Extraction from Grapevine Cultivars and Vitis Species. Plant Molecular Biology Reporter, 12, 6-13. http://dx.doi.org/10.1007/BF02668658

[22] Ramos, M., Rocheta, M., Carvalho, L., Inácio, V., Graça, J. and Morais-Cecilio, L. (2013) Expression of DNA Methyltransferases Is Involved in Quercus Suber Cork Quality. Tree Genetics \& Genomes, 9, 1481-1492. http://dx.doi.org/10.1007/s11295-013-0652-6

[23] Chinnusamy, V. and Zhu, J.K. (2009) Epigenetic Regulation of Stress Responses in Plants. Current Opinion in Plant Biology, 12, 133-139. http://dx.doi.org/10.1016/j.pbi.2008.12.006

[24] Boyko, A. and Kovalchuk, I. (2011) Genome Instability and Epigenetic Modification-Heritable Responses to Environmental Stress? Current Opinion in Plant Biology, 14, 1-7. http://dx.doi.org/10.1016/j.pbi.2011.03.003

[25] Ferreira, L.J., Azevedo, V., Maroco, J., Oliveira, M.M. and Santos, A.P. (2015) Salt Tolerant and Sensitive Rice Varieties Display Differential Methylome Flexibility under Salt Stress. PLoS ONE, 10, e0124060. http://dx.doi.org/10.1371/journal.pone.0124060

[26] Tulmann Neto, A., Ando, A. and Mendes, B.M.J. (1990) Ampliação da variabilidade genética em algumas frutíferas através da indução de mutações “in Vivo” e "in Vitro". In: Ed., Primeiro Simpósio Latino-Americano sobre Recursos Genéticos de Espécies Hortícolas, Fundação Cargil, Campinas, Vol. 1, 148-169.

[27] Spiegel-Roy, P. (1990) Economic and Agricultural Impact of Mutation Breeding in Fruit Trees. Mutation Breeding Review, 5, 26.

[28] Akuhund-Zade, I.M. (1981) Radiation Mutagenesis in Subtropical Crops. Teor Prikl Aspekty Radiata Biology Technology, 10-12, 50-51.

[29] Kim, J.E., Lee, M.H., Cho, E.J., Kim, J.H., Chung, B.Y. and Hong, J. (2013) Characterization of Non-CG Genomic Hypomethylation Associated with Gamma-Ray-Induced Suppression of CMT3 Transcription in Arabidopsis thaliana. Radiation Research, 180, 638-648. http://dx.doi.org/10.1667/RR13394.1

[30] Zhang, X., Yazaki, J., Sundaresan, A., Cokus, S., Chan, S.W., Chen, H., Henderson, I.R., Shinn, P., Pellegrini, M., Jacobsen, S.E. and Ecker, J.R. (2006) Genome-Wide High Resolution Mapping and Functional Analysis of DNA Methylation in Arabidopsis. Cell, 126, 1189-1201. http://dx.doi.org/10.1016/j.cell.2006.08.003

[31] Zhu, J., Kapoor, A., Sridhar, V.V., Agius, F. and Zhu, J.K. (2007) The DNA Glycosylase/lyaseROS1 Functions in Pruning DNA Methylation Patterns in Arabidopsis. Current Biology, 17, 54-59. http://dx.doi.org/10.1016/j.cub.2006.10.059

[32] Grewal, S.I.S. and Rice, J.C. (2004) Regulation of Heterochromatin by Histone Methylation and Small RNAs. Current Opinion in Cell Biology, 16, 230-238. http://dx.doi.org/10.1016/j.ceb.2004.04.002

[33] Lister, R., O’Malley, R.C., Tonti-Filippini, J., Gregory, B.D., Berry, C.C., Millar, A.H. and Ecker, J.R. (2008) Highly Integrated Single-Base Resolution Maps of the Epigenome in Arabidopsis. Cell, 133, 523-536. http://dx.doi.org/10.1016/j.cell.2008.03.029

[34] Lippman, Z. and Martienssen, R.A. (2004) The Role of RNA Interference in Heterochromatic Silencing. Nature, 431, 364-370. http://dx.doi.org/10.1038/nature02875

[35] He, X., Chen, T. and Zhu, J. (2011) Regulation and Function of DNA Methylation in Plants and Animals. Cell Research, 21, 442-465. http://dx.doi.org/10.1038/cr.2011.23 